\title{
ACTIVATION OF LACTOPEROXIDASE (LP) SYSTEM IN MILK AND ITS EFFECT ON THE QUALITY OF KAREISH CHEESE
}

\author{
EL-AHWAL, R.I.; SALA, E. ABO EL-KHER AND HATTEM, H. E.
}

Dairy Chemistry Department, A.R.C. Animal Production Research Institute, Dokki, Giza, Egypt. Drhamed2025@yahoo.com

(Manuscript received 13 August 2018)

\begin{abstract}
I $\mathrm{n}$ the present study, Lactoperoxidase system (LPS) was activated in fresh cow's milk. The $\mathrm{pH}$ and acidity of treated milk were followed during storage at room $\left(32^{\circ} \mathrm{C}\right)$, incubator $\left(37^{\circ} \mathrm{C}\right)$ and refrigerator $\left(5 \pm 1^{\circ} \mathrm{C}\right)$ temperatures. The activation was done using $\mathrm{SCN}$ and $\mathrm{H} 2 \mathrm{O} 2$ or $\mathrm{SCN}^{-}$and $\mathrm{Na} 2 \mathrm{CO} 3.1 .5 \mathrm{H} 2 \mathrm{O} 2$. The effect of activation on microbiological quality was also investigated. All the treatments greatly improved the keeping quality of milk at room or higher temperatures compared to the untreated samples. The best results were achieved by adding $14 \mathrm{mg} \mathrm{SCN} / \mathrm{L}: 2 \mathrm{~mL} \mathrm{H} 2 \mathrm{O} 2 / \mathrm{L}$ to cow's milk. In addition, slight improvement in the keeping quality of the LP-activated milk was observed when the milk was kept in a refrigerator. kareish cheese was made from cow's milk preserved by the LPS and the effect of the LPS on the chemical, microbiological and sensory properties of kareish cheese storaged for 30 days was investigated. Kareish cheese made from LPactivated cow's milk was low in total bacterial count when compared to cheese made from the untreated one (control). The LP treatment did not affect the overall chemical composition of the cheese. Activation of LP system allowed to produce of kareish cheese with high and keeping quality.

Keywords: Lactoperoxidase system, cow's milk, kareish cheese
\end{abstract}

\section{INTRODUCTION}

Kareish cheese is one of the most popular cheese varieties consumed in Egypt especially in countryside owing to its high protein, low fat and reasonable price. It has a limited shelf life of 7-11 days. This may be due to sanitary problems during manufacture cheese (uncontrolled hygiene) which increase microbial contamination. Yeasts and moulds play an important role in the spoilage of dairy products and kareish cheese particular. It also may impair public health due to the presence of mycotoxins which cause carcinogenic health problems. The microbial quality and safety of kareish cheese is the major area of concern for producers and consumers. Therefore, there is a need to develop and to improve the kareish cheese quality, and increase its shelf life.

The lactoperoxidase system (LPS) is one of several natural antibacterial systems found in bovine and other mammalian milks. The LP-system consists of: (i) lactoperoxidase (LP) enzyme, which is present in milk in sufficient amounts. It is the 
most abundant enzyme in cow's milk (up to $50 \mathrm{mg} / \mathrm{L}$ ). It is a heat stable and can retain its normal activity after pasteurization at $63^{\circ} \mathrm{C} / 30$ minutes or $72^{\circ} \mathrm{C} / 15$ seconds, but it is destroyed at $80^{\circ} \mathrm{C}$ in 2.5 seconds: (ii) thiocyanate $\left(\mathrm{SCN}^{-}\right.$) that is present in varying amounts in cows' milk, depending on dietary intake, may need adjustment of its concentration to activate LP-system. The LPS has been recognized as critical in the dairy industry for the preservation of raw milk (Haddadin, et al., 1996), pasteurized milk and cheese (Earnshaw, et al., 1989).. The system also serves as a processing aid in the production of other dairy products (García-Graells, et al., 2000). In Africa, application of the LPS was firstly tested in Kenya (Bjorck, et al., 1979) as a successful means of preserving milk at ambient temperatures. Moreover, a strong effect of the LP-system against gram-negative psychrotrophs was demonstrated. It was also reported that the activation of the LPS in milk could offer an immediate and practical solution to prolong the shelf-life of milk in warm countries (Mehanna, et al., 1998). The objective of the present study was to determine the effect of the activated lactoperoxidase (LP)-system on keeping quality of cow's milk as well as the manufactured kareish cheese using LP-activated cow's milk.

\section{MATERIALS AND METHODS}

\section{Activation of the LP-Systems:-}

Fresh cow's milk samples were collected from qbur center. Twenty raw milk samples, approximately $1000 \mathrm{ml}$ each, were collected in sterilized Pyrex bottles within one hour of milking at 6 a.m. The samples were immediately placed in a box with ice

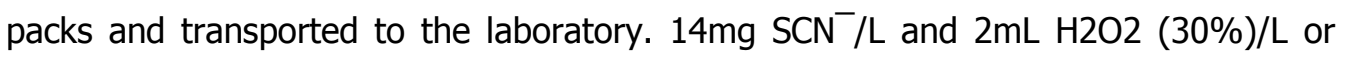
$14 \mathrm{mg} \mathrm{SCN}-/ \mathrm{L}$ and $30 \mathrm{mg}$ sodium per carbonate/L were prepared. Each of these combinations was added to $100 \mathrm{ml}$ milk. In addition, control cow's milk samples were kept for further analyses, without any treatment. The tested milk samples were kept at room temperature $\left(32^{\circ} \mathrm{C}\right)$, in incubator $\left(37^{\circ} \mathrm{C}\right)$ for 6 hours, and the cold storage of milk was done at $5 \pm 1^{\circ} \mathrm{C}$ for 3 days.

\section{Manufacture of kareish cheese:-}

The kareish cheese was manufactured as described by Effat, et al., (2001). The cheese samples were kept in plastic pouches and stored at $5 \pm 1^{\circ} \mathrm{C}$ for 30 days and analyzed at zero time, after 7, 14, 21 and 30 day of storage.

\section{Chemical Composition:-}

The $\mathrm{pH}$ of cow's milk samples were determined by using $\mathrm{pH}$ meter model CG 840, Toshiba, Japan. The titratable acidity (expressed as lactic acid percent) was estimated for different milk samples according to AOAC (2002) methods. Protein, fat, 
ash and moisture contents of cheese samples were also determined according to AOAC (2002).

\section{Microbiological Analysis:-}

The microbiological analysis was carried out according to International Dairy Federation (1990).

\section{Organoleptic properties:-}

The organoleptic properties of kareish cheese were evaluated according to ElShafei, et al., (2008). The samples were presented to the panelists in a random order. The cheeses were evaluated organoleptically at zero time, after 7, 14, 21 and 30 days of storage at $5 \pm 1^{\circ} \mathrm{C}$. Panelists evaluated cheese for appearance (20 points), body and texture (45 points), and flavour (35 points). Overall acceptability (100 points) scores were obtained for all sensory attributes.

\section{Statistical analysis:-}

The obtained data were statistically analyzed for analysis of variance, averages and Duncan's test according to SPSS computer program (SPSS, 1998).

\section{RESULTS AND DISCUSSION}

Table (1) presented the acidity \% expressed as lactic acid and $\mathrm{pH}$ values of cow's milk treated with $\mathrm{SCN}^{-}$and $\mathrm{H} 2 \mathrm{O} 2$ at rate of, $14 \mathrm{mg} / \mathrm{L}$ and $2 \mathrm{~mL} / \mathrm{L}$, respectively and kept at room $\left(32^{\circ} \mathrm{C}\right)$, incubator $\left(37^{\circ} \mathrm{C}\right)$ and refrigerator $\left(5 \pm 1^{\circ} \mathrm{C}\right)$. Significant $(\mathrm{P} \leq 0.05)$ changes in acidity $\%$ and $\mathrm{pH}$ value were recorded in both control and LPsystem activated cow's milk kept at room temperature. However, the significantly $(P \leq 0.05)$ increased with time reaching $0.31 \%$ at the end of the storage time in cow's milk kept at room temperature. On the other hand, the acidity of treated cow's milk at the seven hours of storage at room temperatures was recorded as $0.25 \%$. The corresponding decrease in $\mathrm{pH}$ was gradual but significant. At incubator temperature, highly significant changes in acidity and $\mathrm{pH}$ were recorded in all control and treated milk samples. However, values of $\mathrm{pH}$ and acidity of control and treated milk samples kept at room temperature were slightly different from those kept in incubator and refrigerator during the same storage time. The findings indicate the importance of preserving raw milk by activation of LP-system. On contrast, these findings were agreed with Mehanna, et al., (1998), who reported that LP-system improved the keeping quality of milk. Activation of the LP-system by adding $\mathrm{SCN}^{-}$: $\mathrm{H} 2 \mathrm{O} 2$ at rate of $14 \mathrm{mg} / \mathrm{L}: 2 \mathrm{~mL} / \mathrm{L}$ was more effective in cow's milk stored at both room and incubator temperatures. 
Table 1. Effect of adding $14 \mathrm{mg}$ thiocyanate/ $\mathrm{L}$ and $2 \mathrm{~mL}$ of hydrogen peroxide/ $\mathrm{L}$ on the $\mathrm{pH}$ and acidity $(\%)$ in cow's milk kept at room $\left(32^{\circ} \mathrm{C}\right)$, incubator $\left(37^{\circ} \mathrm{C}\right)$ and refrigerator $\left(5 \pm 1^{\circ} \mathrm{C}\right)$ temperature.

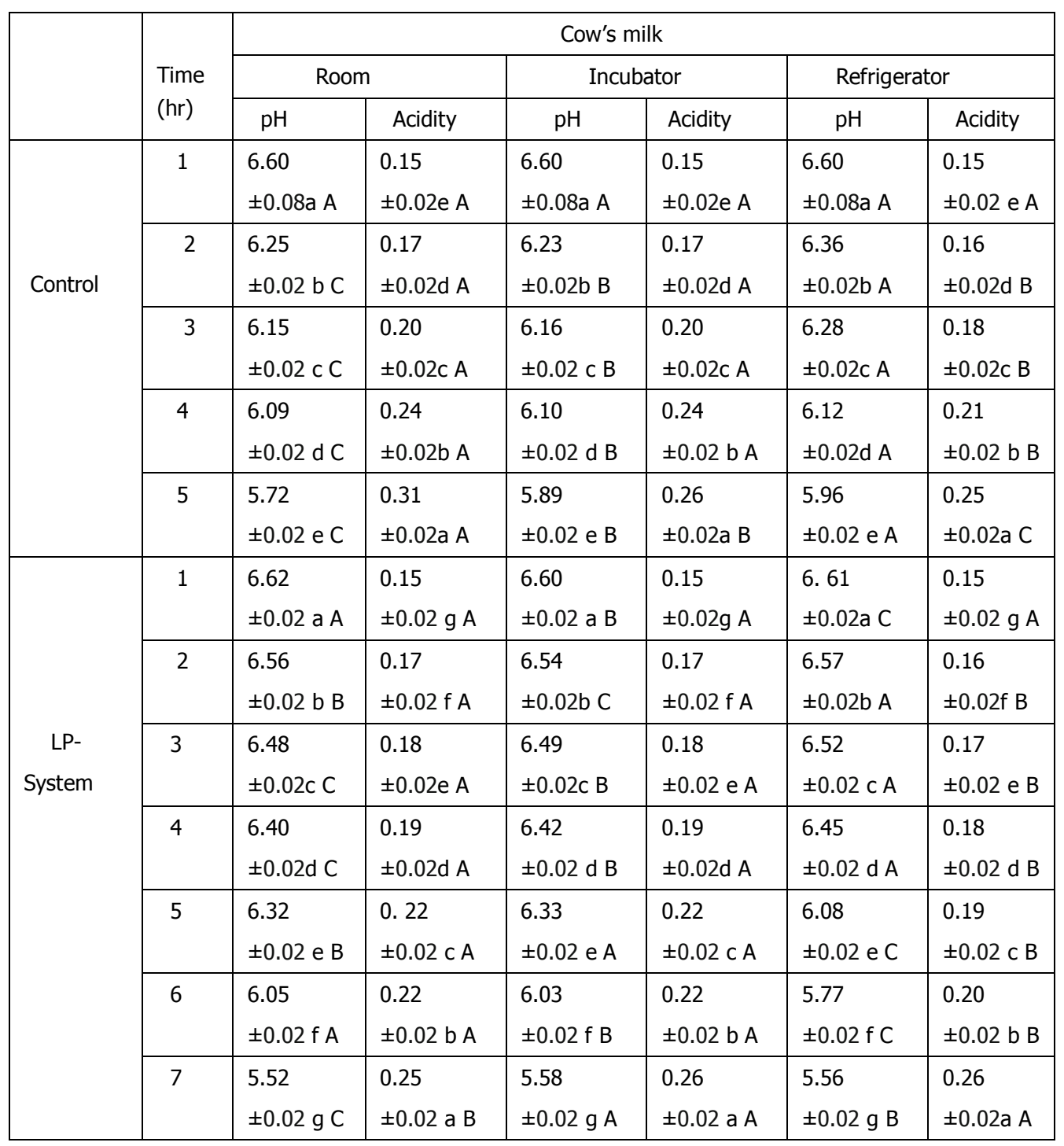

Means \pm standard error. $a, b, c$ Means within the same column with different letters are significantly different $(P \leq 0.05)$.

$A, B, C$ Means within the same row with different letters are significantly different $\quad(P \leq 0.05)$.

The data given in Table (2) reveal that activation of the LP-system by adding $\mathrm{SCN}^{-}$: Na2CO3 at rate of $14 \mathrm{mg} / \mathrm{L}: 30 \mathrm{mg} / \mathrm{L}$ respectively. This was more effective in the case of cow's milk stored at both given temperatures. This means that activation of the LP-system gave the best results with cow's milk at any given storage temperature. Also, the lower the storage temperature, the higher was the effectiveness of the LP-system. Their agreed with the findings of Bjorck et al., (1979) who reported that the action of the LP system was temperature dependent. 
Table 2. Effect of adding $14 \mathrm{mg}$ thiocyanate/L and $30 \mathrm{mg}$ of sodium per carbonate/L on the changes in $\mathrm{pH}$ and acidity (\%) in cow's milk kept at room $\left(32^{\circ} \mathrm{C}\right)$, incubator $\left(37^{\circ} \mathrm{C}\right)$ and refrigerator $\left(5 \pm 1^{\circ} \mathrm{C}\right)$ temperatures.

\begin{tabular}{|c|c|c|c|c|c|c|c|}
\hline & \multirow{3}{*}{$\begin{array}{l}\text { Time } \\
(\mathrm{hr})\end{array}$} & \multicolumn{6}{|c|}{ Cow's milk kept } \\
\hline & & \multicolumn{2}{|c|}{ Room } & \multicolumn{2}{|c|}{ Incubator } & \multicolumn{2}{|c|}{ Refrigerator } \\
\hline & & $\mathrm{pH}$ & Acidity & $\mathrm{pH}$ & Acidity & $\mathrm{pH}$ & Acidity \\
\hline \multirow{5}{*}{ Control } & 1 & $\begin{array}{l}6.60 \\
\pm 0.02 \text { a A }\end{array}$ & $\begin{array}{l}0.15 \\
\pm 0.02 \text { e A }\end{array}$ & $\begin{array}{l}6.60 \\
\pm 0.02 \mathrm{a} \mathrm{A}\end{array}$ & $\begin{array}{l}0.15 \\
\pm 0.02 \text { e } A\end{array}$ & $\begin{array}{l}6.60 \\
\pm 0.02 \text { a A }\end{array}$ & $\begin{array}{l}0.15 \\
\pm 0.02 \text { e } A\end{array}$ \\
\hline & 2 & $\begin{array}{l}6.55 \\
\pm 0.02 \mathrm{~b} \mathrm{~A}\end{array}$ & $\begin{array}{l}0.17 \\
\pm 0.02 \mathrm{~d} \mathrm{C}\end{array}$ & $\begin{array}{l}5.53 \\
\pm 0.02 \mathrm{~b} \mathrm{C}\end{array}$ & $\begin{array}{l}0.173 \\
\pm 0.02 \mathrm{~d} \mathrm{~B}\end{array}$ & $\begin{array}{l}6.36 \\
\pm 0.02 \mathrm{~b} \mathrm{~B}\end{array}$ & $\begin{array}{l}0.183 \\
\pm 0.02 \mathrm{~d} \mathrm{~A}\end{array}$ \\
\hline & 3 & $\begin{array}{l}6.45 \\
\pm 0.02 \text { с B }\end{array}$ & $\begin{array}{l}0.20 \\
\pm 0.02 \text { c C }\end{array}$ & $\begin{array}{l}6.49 \\
\pm 0.02 \text { с A }\end{array}$ & $\begin{array}{l}0.224 \\
\pm 0.02 \mathrm{c} \mathrm{A}\end{array}$ & $\begin{array}{l}6.18 \\
\pm 0.02 \text { c C }\end{array}$ & $\begin{array}{l}0.201 \\
\pm 0.02 \mathrm{c} \mathrm{B}\end{array}$ \\
\hline & 4 & $\begin{array}{l}6.29 \\
\pm 0.02 \mathrm{~d} \mathrm{~B}\end{array}$ & $\begin{array}{l}0.24 \\
\pm 0.02 \text { b B }\end{array}$ & $\begin{array}{l}6.42 \\
\pm 0.02 \mathrm{~d} \mathrm{~A}\end{array}$ & $\begin{array}{l}0.243 \\
\pm 0.02 \mathrm{~b} \mathrm{~A}\end{array}$ & $\begin{array}{l}5.88 \\
\pm 0.02 \mathrm{~d} \mathrm{C}\end{array}$ & $\begin{array}{l}0.232 \\
\pm 0.02 \mathrm{bC}\end{array}$ \\
\hline & 5 & $\begin{array}{l}5.92 \\
\pm 0.02 \text { e } B\end{array}$ & $\begin{array}{l}0.31 \\
\pm 0.02 \text { a A }\end{array}$ & $\begin{array}{l}6.29 \\
\pm 0.02 \text { e A }\end{array}$ & $\begin{array}{l}0.262 \\
\pm 0.02 \text { a C }\end{array}$ & $\begin{array}{l}5.66 \\
\pm 0.02 \mathrm{eC}\end{array}$ & $\begin{array}{l}0.273 \\
\pm 0.02 \text { a B }\end{array}$ \\
\hline \multirow{7}{*}{$\begin{array}{c}\text { LP- } \\
\text { System }\end{array}$} & 1 & $\begin{array}{l}6.95 \\
\pm 0.02 \text { a A }\end{array}$ & $\begin{array}{l}0.15 \\
\pm 0.02 \mathrm{~g} \mathrm{C}\end{array}$ & $\begin{array}{l}6.58 \\
\pm 0.02 \text { a C }\end{array}$ & $\begin{array}{l}0.153 \\
\pm 0.02 \text { a B }\end{array}$ & $\begin{array}{l}6.61 \\
\pm 0.02 \text { a B }\end{array}$ & $\begin{array}{l}0.154 \\
\pm 0.02 \mathrm{~g} \mathrm{~A}\end{array}$ \\
\hline & 2 & $\begin{array}{l}6.56 \\
\pm 0.02 \mathrm{~b} \mathrm{~A}\end{array}$ & $\begin{array}{l}0.16 \\
\pm 0.02 \mathrm{fC}\end{array}$ & $\begin{array}{l}6.54 \\
\pm 0.02 \mathrm{~b} \mathrm{~A}\end{array}$ & $\begin{array}{l}0.164 \\
\pm 0.02 \text { a B }\end{array}$ & $\begin{array}{l}6.47 \\
\pm 0.02 \text { b B }\end{array}$ & $\begin{array}{l}0.172 \\
\pm 0.02 \mathrm{f} \mathrm{A}\end{array}$ \\
\hline & 3 & $\begin{array}{l}6.51 \\
\pm 0.02 \mathrm{c} \mathrm{A}\end{array}$ & $\begin{array}{l}0.17 \pm \\
0.02 \text { e C }\end{array}$ & $\begin{array}{l}6.51 \\
\pm 0.02 \mathrm{cA}\end{array}$ & $\begin{array}{l}0.183 \\
\pm 0.02 \text { a B }\end{array}$ & $\begin{array}{l}6.21 \\
\pm 0.02 \mathrm{c} \mathrm{B}\end{array}$ & $\begin{array}{l}0.194 \\
\pm 0.02 \mathrm{eA}\end{array}$ \\
\hline & 4 & $\begin{array}{l}6.40 \\
\pm 0.02 \mathrm{~d} \mathrm{~B}\end{array}$ & $\begin{array}{l}0.18 \\
\pm 0.02 \mathrm{~d} \mathrm{C}\end{array}$ & $\begin{array}{l}6.46 \\
\pm 0.02 \mathrm{~d} \mathrm{~A}\end{array}$ & $\begin{array}{l}0.222 \\
\pm 0.02 \text { a A }\end{array}$ & $\begin{array}{l}6.10 \\
\pm 0.02 \mathrm{~d} \mathrm{C}\end{array}$ & $\begin{array}{l}0.203 \\
\pm 0.02 \mathrm{~d} \mathrm{~B}\end{array}$ \\
\hline & 5 & $\begin{array}{l}6.32 \\
\pm 0.02 \text { e B }\end{array}$ & $\begin{array}{l}0.20 \\
\pm 0.02 \text { c B }\end{array}$ & $\begin{array}{l}6.43 \\
\pm 0.02 \text { e } A\end{array}$ & $\begin{array}{l}0.223 \\
\pm 0.02 \text { a } A\end{array}$ & $\begin{array}{l}5.98 \\
\pm 0.02 \text { e C }\end{array}$ & $\begin{array}{l}0.223 \\
\pm 0.02 \mathrm{c} \mathrm{A}\end{array}$ \\
\hline & 6 & $\begin{array}{l}6.05 \\
\pm 0.02 \mathrm{f} \mathrm{B}\end{array}$ & $\begin{array}{l}0.22 \\
\pm 0.02 \mathrm{~b} \mathrm{C}\end{array}$ & $\begin{array}{l}6.21 \\
\pm 0.02 \mathrm{fA}\end{array}$ & $\begin{array}{l}0.262 \\
\pm 0.02 \text { a A }\end{array}$ & $\begin{array}{l}5.77 \\
\pm 0.02 \mathrm{fC}\end{array}$ & $\begin{array}{l}0.242 \\
\pm 0.02 \mathrm{~b} \mathrm{~B}\end{array}$ \\
\hline & 7 & $\begin{array}{l}5.92 \\
\pm 0.02 \mathrm{~g} \mathrm{~B}\end{array}$ & $\begin{array}{l}0.25 \\
\pm 0.02 \text { a C }\end{array}$ & $\begin{array}{l}5.98 \\
\pm 0.02 \mathrm{~g} \mathrm{~A}\end{array}$ & $\begin{array}{l}0.273 \\
\pm 0.02 \text { a A }\end{array}$ & $\begin{array}{l}5.56 \\
\pm 0.02 \mathrm{~g} \mathrm{C}\end{array}$ & $\begin{array}{l}0.262 \\
\pm 0.02 \text { a B }\end{array}$ \\
\hline
\end{tabular}

Means \pm standard error. $a, b, c$ Means within the same column with different letters are significantly different $(P<0.05) . A, B, C$ Means within the same raw with different letters are significantly different $\quad(P$ $<0.05)$.

Results of hygienic quality and bacterial counts demonstrate that activation of the LP-systems in raw cow's milk samples kept at $30^{\circ} \mathrm{C}$ and $5^{\circ} \mathrm{C}$ improved the keeping quality.

Further, since the effectiveness of the LP-systems is dependent upon the initial of microbiological quality of milk (Härnulv and Kandasamy, 1982). The best effect of LP-systems is obtained if the activation is slightly later when bacterial multiplication would normally have started where the indigenous antibacterial systems still had a considerable effect. Moreover, activation of the LP-systems could be considered the base of a method for suppressing the growth of lactic-producing organisms in uncooled milk (El-Agamy, et al., 1993). At $10^{\text {th }}$ hour the mean total bacterial counts (TBC) of treated samples definitely increased to be $4 \times 106 \mathrm{cfu} / \mathrm{mL}$, while the initial mean TBC at 0 hour was $2.5 \times 105 \mathrm{cfu} / \mathrm{mL}$ (Table, 3). The controls passed that level after $4^{\text {th }}$ hour. Slightly lower findings were recorded by Bennett, (2000). 
Table 3. Total bacterial counts (TBC) of the examined raw cow's milk samples treated with LPS after 3 hours of milking and kept at $30^{\circ} \mathrm{C}$ for 12 hours

\begin{tabular}{|c|c|c|}
\hline \multirow{2}{*}{ Time (hr) } & \multicolumn{2}{|c|}{ Means of TBC cfu/ $/ \mathrm{mL}$} \\
\cline { 2 - 3 } & Control & LP- system \\
\hline 0 & $2.6 \times 10^{2} \mathrm{a}$ & $2.5 \times 105 \mathrm{~b}$ \\
\hline 2 & $2.6 \times 106 \mathrm{a}$ & $5.0 \times 105 \mathrm{~b}$ \\
\hline 4 & $3.8 \times 106 \mathrm{a} *$ & $3.0 \times 106 \mathrm{~b}$ \\
\hline 6 & $4.5 \times 106 \mathrm{a}$ & $3.6 \times 106 \mathrm{~b}$ \\
\hline 8 & $5.1 \times 107 \mathrm{a}$ & $3.6 \times 106 \mathrm{~b}$ \\
\hline 10 & - & $4.0 \times 106 *$ \\
\hline 12 & - & $2.7 \times 107$ \\
\hline
\end{tabular}

$a, b, c$ Means within the same row with different letters are significantly different $\quad(P<0.05)$.

Results recorded in Table (4) declared that mean psychrotrophic counts (PC) of examined raw cow's milk samples at $5^{\circ} \mathrm{C}$ was $2.6 \times 106 \mathrm{cfu} / \mathrm{mL}$ at the 6 th day that definitely increased to $1.3 \times 107 \mathrm{cfu} / \mathrm{mL}$ at the $7^{\text {th }}$ day of storage period, while the initial mean (PC) was $5.5 \times 103 \mathrm{cfu} / \mathrm{mL}$. However, the controls have passed those levels at the 2 nd day. An extension of about 4 days is indicated. The results were substantiating those given by Lin and Chow, (2000) for different milk types.

It was concluded from the obtained results that the pronounced differences in hygienic quality and bacterial counts between activated and control raw cow's milk samples were evidenced. The bacteriostatic effect generate from the activation of LPsystems in raw cow's milk prolonged the time of storage (shelf-life) by decreasing acidity caused by microbial flora present in raw milk (Stefano, et al., 1995) at temperature $30^{\circ} \mathrm{C}$ and $5^{\circ} \mathrm{C}$ for 6 hours and 4 days, respectively. Even an increase of about 6 hours and 4 days in shelf life of Lp activated milk, with 15 ppm KSCN and 10 ppm $\mathrm{H} 2 \mathrm{O} 2$, could be considered to be of practical importance in salvaging border-line milk from souring.

Finally, stabilization of raw milk through activation of LP-systems considered to be a useful method for extending the shelf-life of milk in Egypt and tropical countries. It should be emphasized that the method of milk quality preservation does not exempt milk producers from the duty of observing the general principles of hygiene when handling milk on the farm. Stabilization of milk by activation of its LPsystems is a method to keep good quality milk but not a mean of concealing or improving bad quality milk. In addition, encourage dairy farming by minimizing spoilage, cutting costs of transportation and facilitating the collection of milk from remote areas (Miur, and Banks, 2000). 
Regarding to the possible health risks of using the LP-systems, the only concern could arise from the SCN-, which known as a goitrogenic agent. However, an excellent review by Reiter and Härnulv, (1984) reported that the most important studies made so far on that subject. It is possible to say that even using potency level of about $42 \mathrm{ppm}$ of SCN-, the system is not expected to indirectly pose any risk for the consumer. The $\mathrm{H} 2 \mathrm{O} 2$ does not present any health hazard because it fades out few hours after its addition, since it is consumed as substrate by the system, yielding $\mathrm{H} 2 \mathrm{O}$. Moreover, the inhibitor formed by the reaction, OSCN- among other, is not stable to the pasteurization treatment, so there is no inhibitor remaining; in the event there were any, stated that it will not affect adversely human cells and organs. Furthermore, it has been suggested by some researchers that the LP-systems exists in the mouth and may play a role against the microorganisms responsible for oral cavities. There is direct evidence that the LP-system occurs in man because one of the oxidation products of thiocyanate (hypothio cyanate) was recently detected in saliva.

Table 4. Psychrotrophic counts (PC) of the examined raw cow's milk treated with LP- system after 3 hours of milking then kept at $5 \pm 1^{\circ} \mathrm{C}$

\begin{tabular}{|l|c|c|}
\hline \multirow{2}{*}{ Time/days } & \multicolumn{2}{|c|}{ Means of PC cfu/mL } \\
\cline { 2 - 3 } & Control & LP- System \\
\hline 0 & $5.5 \times 10^{3} \mathrm{a}$ & $4.5 \times 10^{3} \mathrm{~b}$ \\
\hline 1 & $8.6 \times 104 \mathrm{a}$ & $7.2 \times 10^{3} \mathrm{~b}$ \\
\hline 2 & $1.3 \times 106^{*} \mathrm{a}$ & $1.2 \times 104 \mathrm{~b}$ \\
\hline 3 & $2.5 \times 107 \mathrm{a}$ & $1.8 \times 105 \mathrm{~b}$ \\
\hline 4 & $5.5 \times 107 \mathrm{a}$ & $3.1 \times 105 \mathrm{~b}$ \\
\hline 5 & - & $5.5 \times 105$ \\
\hline 6 & - & $2.6 \times 106^{*}$ \\
\hline 7 & - & $1.3 \times 107$ \\
\hline
\end{tabular}

$a, b, c$ Means within the same row with different letters are significantly different $\quad(P \leq 0.05)$.

Table (5) recorded the chemical composition of kareish cheese during the storage period of all samples. The moisture content of kareish cheese manufactured by activated LP- system gradually decreased till the end of storage period, with significant differences among the samples of LP- system treated cheese. The results were in agreement with that reported by Aldo, et al., (2013). Slight differences were noticed among kareish cheese in ash, titratable acidity, fat and protein contents throughout the storage period which indicating that, LP- system had slight effect on the composition of the resulted cheese. The results were in agreement with that reported by (Aldo et al., 2013). 
Table 5. Chemical composition of kareish cheese as affected by activation of LPsystem during the storage period at $5 \pm 1^{\circ} \mathrm{C}$

\begin{tabular}{|c|c|c|c|c|c|c|}
\hline Treatments & $\begin{array}{c}\text { Storage } \\
\text { period } \\
\text { days }\end{array}$ & $\begin{array}{c}\text { Moisture } \\
\% \\
\end{array}$ & $\begin{array}{c}\text { Fat } \\
\%\end{array}$ & $\begin{array}{c}\text { Protein } \\
\%\end{array}$ & $\begin{array}{c}\text { Ash } \\
\%\end{array}$ & $\begin{array}{c}\text { Titratable } \\
\text { acidity } \\
\% \\
\end{array}$ \\
\hline \multirow{5}{*}{ Control } & Zero & $\begin{array}{r}76.80 \\
\pm 1.32 \mathrm{a} \\
\end{array}$ & $\begin{array}{c}0.90 \\
\pm 0.01 \mathrm{~d} \\
\end{array}$ & $\begin{array}{r}16.50 \\
\pm 0.82 \mathrm{a} \\
\end{array}$ & $\begin{array}{c}3.40 \\
\pm 0.22 \mathrm{e} \\
\end{array}$ & $\begin{array}{c}1.10 \\
\pm 0.02 \mathrm{e} \\
\end{array}$ \\
\hline & 7 & $\begin{array}{c}75.54 \\
\pm 1.62 \mathrm{~b} \\
\end{array}$ & $\begin{array}{c}0.90 \\
\pm 0.02 \mathrm{c} \\
\end{array}$ & $\begin{array}{c}15.92 \\
\pm 0.62 \mathrm{~b} \\
\end{array}$ & $\begin{array}{c}3.49 \\
\pm 0.32 \mathrm{~d} \\
\end{array}$ & $\begin{array}{c}1.21 \\
\pm 0.01 \mathrm{~d} \\
\end{array}$ \\
\hline & 14 & $\begin{array}{c}74.64 \\
\pm 1.42 \mathrm{c} \\
\end{array}$ & $\begin{array}{c}0.95 \\
\pm 0.04 \mathrm{~b} \\
\end{array}$ & $\begin{array}{c}15.70 \\
\pm 0.92 \mathrm{c} \\
\end{array}$ & $\begin{array}{c}3.62 \\
\pm 0.12 \mathrm{c} \\
\end{array}$ & $\begin{array}{c}1.35 \\
\pm 0.04 \mathrm{c} \\
\end{array}$ \\
\hline & 21 & $\begin{array}{r}73.00 \\
\pm 1.7 \mathrm{~d} \\
\end{array}$ & $\begin{array}{r}1.00 \\
\pm 0.01 \mathrm{a} \\
\end{array}$ & $\begin{array}{c}15.58 \\
\pm 0.72 \mathrm{~d} \\
\end{array}$ & $\begin{array}{c}3.68 \\
\pm 0.42 \mathrm{~b} \\
\end{array}$ & $\begin{array}{c}1.45 \\
\pm 0.03 \mathrm{~b} \\
\end{array}$ \\
\hline & 30 & $\begin{array}{r}72.10 \\
\pm 1.92 \mathrm{e} \\
\end{array}$ & $\begin{array}{r}1.00 \\
\pm 0.05 \mathrm{a} \\
\end{array}$ & $\begin{array}{r}15.50 \\
\pm 0.52 \mathrm{e} \\
\end{array}$ & $\begin{array}{c}3.75 \\
\pm 0.12 \mathrm{a} \\
\end{array}$ & $\begin{array}{c}1.58 \\
\pm 0.06 a \\
\end{array}$ \\
\hline \multirow{5}{*}{$\begin{array}{l}\text { LP- } \\
\text { System }\end{array}$} & Zero & $\begin{array}{c}77.12 \\
\pm 2.12 \mathrm{a} \\
\end{array}$ & $\begin{array}{r}1.00 \\
\pm 0.12 \mathrm{a} \\
\end{array}$ & $\begin{array}{c}16.70 \\
\pm 0.42 \mathrm{a} \\
\end{array}$ & $\begin{array}{c}3.10 \\
\pm 0.42 \mathrm{e} \\
\end{array}$ & $\begin{array}{c}0.96 \\
\pm 0.04 \mathrm{e} \\
\end{array}$ \\
\hline & 7 & $\begin{array}{c}75.90 \\
\pm 2.22 \mathrm{~b} \\
\end{array}$ & $\begin{array}{c}1.00 \\
\pm 0.05 \mathrm{a} \\
\end{array}$ & $\begin{array}{c}16.12 \\
\pm 0.62 \mathrm{~b} \\
\end{array}$ & $\begin{array}{c}3.17 \\
\pm 0.52 \mathrm{~d} \\
\end{array}$ & $\begin{array}{c}0.12 \\
\pm 0.05 \mathrm{~d} \\
\end{array}$ \\
\hline & 14 & $\begin{array}{r}75.00 \\
\pm 2.62 \mathrm{c} \\
\end{array}$ & $\begin{array}{c}1.10 \\
\pm 0.08 \mathrm{a} \\
\end{array}$ & $\begin{array}{c}15.91 \\
\pm 0.82 \mathrm{c} \\
\end{array}$ & $\begin{array}{c}3.22 \\
\pm 0.62 \mathrm{c} \\
\end{array}$ & $\begin{array}{c}0.23 \\
\pm 0.03 \mathrm{c} \\
\end{array}$ \\
\hline & 21 & $\begin{array}{c}74.10 \\
\pm 2.42 \mathrm{~d} \\
\end{array}$ & $\begin{array}{c}1.10 \\
\pm 0.06 \mathrm{a} \\
\end{array}$ & $\begin{array}{c}15.82 \\
\pm 0.72 \mathrm{~d} \\
\end{array}$ & $\begin{array}{r}3.30 \\
\pm 0.72 \mathrm{~b} \\
\end{array}$ & $\begin{array}{c}1.26 \\
\pm 0.02 \mathrm{~b} \\
\end{array}$ \\
\hline & 30 & $\begin{array}{r}73.30 \\
\pm 2.72 \mathrm{e} \\
\end{array}$ & $\begin{array}{r}1.20 \\
\pm 0.09 \mathrm{a} \\
\end{array}$ & $\begin{array}{c}15.61 \\
\pm 0.62 \mathrm{e} \\
\end{array}$ & $\begin{array}{c}3.36 \\
\pm 0.62 \mathrm{a} \\
\end{array}$ & $\begin{array}{c}1.35 \\
\pm 0.01 \mathrm{a} \\
\end{array}$ \\
\hline
\end{tabular}

Means \pm standard error. $a, b$, c Means within the same column with different letters are significantly different $(P<0.05)$.

Table (6) revealed average of total bacterial counts (TBC) of each treatment of kareish cheese samples. The results showed that the TBC was higher in the control sample than that made activated LP- system in milk. During the storage period, the counts decreased gradually and reached its minimum level at the end of the storage period of cold storage. The lipolytic bacteria counts showed in Table (6) were affected by activated LP- system. Lipolytic bacteria were not detected in activated LP- system but it appeared in the control samples. Proteolytic bacteria and coliform were not detected in fresh and during storage period in all kareish cheese. The results were in agreement with Hassan, et al., (2004).

One of the most important parameters to determine the quality and shelf life of kareish cheese is the count of yeast and mould. In addition to quality deterioration, microbiological counts have been used as indices for the end of shelf life of dairy products (Miur and Banks 2000). The counts of mould and yeast were lower than those by Egyptian Standards (2005) being not more than $100 \mathrm{c} 6 \mathrm{u} / \mathrm{g}$. During storage period, the yeast and mould increased gradually and reached the maximum level at the end of storage period for the control. 
Table 6. Some microbiological properties of kareish cheese made with activated LPSystem during cold storage at $5 \pm 1^{\circ} \mathrm{C}$

\begin{tabular}{|c|c|c|c|c|c|c|}
\hline Treatments & $\begin{array}{c}\text { Storage } \\
\text { period } \\
\text { days }\end{array}$ & $\begin{array}{c}\text { Total } \\
\text { bacterial } \\
\text { count } \\
\text { X106 } \\
\text { cfu/g }\end{array}$ & $\begin{array}{c}\text { Lipolytic } \\
\text { bacterial } \\
\text { count } \\
\text { X106 } \\
\mathrm{cfu} / \mathrm{g}\end{array}$ & $\begin{array}{c}\text { Proteolytic } \\
\text { bacterial } \\
\text { count } \\
\mathrm{X} 10^{3} \\
\mathrm{cfu} / \mathrm{g}\end{array}$ & $\begin{array}{l}\text { Coliform } \\
\text { cfu/g }\end{array}$ & $\begin{array}{c}\text { Yeast \& } \\
\text { moulds } \\
\mathrm{X} 10^{3} \\
\mathrm{cfu} / \mathrm{g}\end{array}$ \\
\hline \multirow{5}{*}{ Control } & Zero & $45 \mathrm{a}$ & ND & ND & ND & ND \\
\hline & 7 & $39 a$ & ND & ND & ND & ND \\
\hline & 14 & $25 \mathrm{a}$ & ND & ND & ND & 2 \\
\hline & 21 & $22 \mathrm{a}$ & ND & ND & ND & 4 \\
\hline & 30 & $18 \mathrm{a}$ & ND & ND & ND & 7 \\
\hline \multirow{5}{*}{$\begin{array}{c}\text { LP- } \\
\text { System }\end{array}$} & Zero & $35 \mathrm{~b}$ & ND & ND & ND & ND \\
\hline & 7 & $28 \mathrm{~b}$ & ND & ND & ND & ND \\
\hline & 14 & $20 \mathrm{~b}$ & ND & ND & ND & ND \\
\hline & 21 & $15 \mathrm{~b}$ & ND & ND & ND & ND \\
\hline & 30 & $12 \mathrm{~b}$ & ND & ND & ND & ND \\
\hline
\end{tabular}

$a, b, c$ Means within the same column with different letters are significantly different $\quad(P \leq 0.05)$.

The data presented in Table (7) revealed that the control kareish cheese gained the lowest score either fresh or throughout storage period. Meanwhile the cheese processed with activated LP- system had the highest score during the storage period. In general all cheese made with activated LP- system had acceptable appearance, flavour and body \&texture during the storage period. The results were in agreement with those obtained by Hassan, et al., (2004).

Table 7. Organoleptic assessment of kareish cheese made with activation of LPSystem during the storage period at $5 \pm 1^{\circ} \mathrm{C}$

\begin{tabular}{|c|c|c|c|c|c|}
\hline \multirow{5}{*}{ Treatments } & $\begin{array}{c}\text { Storage } \\
\text { period } \\
\text { days }\end{array}$ & $\begin{array}{c}\text { Appearance } \\
(20)\end{array}$ & $\begin{array}{c}\text { Body } \\
\& \\
\text { texture } \\
(45)\end{array}$ & $\begin{array}{c}\text { Flavour } \\
(35)\end{array}$ & $\begin{array}{c}\text { Total } \\
(100)\end{array}$ \\
\hline \multirow{5}{*}{ Control } & Zero & 18 & 40 & 32 & 90 \\
\cline { 2 - 6 } & 7 & 18 & 40 & 31 & 89 \\
\cline { 2 - 6 } & 14 & 7 & 18 & 16 & 51 \\
\cline { 2 - 6 } & 21 & 5 & 17 & 14 & 36 \\
\cline { 2 - 6 } & 30 & 4 & 10 & 10 & 24 \\
\cline { 2 - 6 } LP- & Zero & 18 & 41 & 32 & 91 \\
\cline { 2 - 6 } & 14 & 18 & 41 & 31 & 89 \\
\cline { 2 - 6 } & 21 & 18 & 40 & 31 & 87 \\
\cline { 2 - 6 } & 30 & 17 & 40 & 30 & 86 \\
\hline
\end{tabular}




\section{CONCLUSION}

The combination of refrigeration and activation of the Lactoperoxidase system in the preparation of kareish cheese is effective to reduce the microbial deterioration during the storage period of kareish cheese.

\section{REFERENCES}

1. Association of Official Analytical Chemists (A.O.A.C.). 2002. Official methods of analysis, 25th (Ed) Arlington VA.USA.

2. Barabas, J. 1995. An alternative method of milk treatment. World Animal Review. Meat and Dairy Service, FAO, Rome, Italy., No. 83: 71-73.

3. Bennett, A. 2000. The lactoperoxidase system (LP-s) of milk preservation. Poster paper. E-mail conference on "Small Scale Milk Collection and Processing in Developing Counteries" - FAO, Rome.

4. Bjorck, L.; Chawsson, O. and Schlthess, W. 1979. The lactoperoxidase thiocyanate hydrogen peroxide system as a temporary preservative for raw milk in developing countries. Milchwissen Schaft 34, 726-728.

5. Earnshaw, R.G. and Francotte, D. 1989. The preservation of Cottage cheese by an activated lactoperoxidase system. Food Microbiol. 6, 285-288.

6. Effat, B.A.; Salem, M.M.E. and El-Shafei, k. 2001. Effect of using different starters on quality of kareish cheese Egypt j. food Sci. 29: 25-108.

7. Egyptian standard for Kareish and Domiati cheese. (2005). Egyptian Organization for standards, quality and control .ES 1008/2000.

8. El-Agamy, E.I.; Shoukry, Y.M.R. and El-ghannam, M.S. 1993. Effect of lactoperoxidase activation system on the shelf-life of raw milk stored at different temperatures. Alex. J. Agric. Res. 38, 351-364.

9. El-Shafei, K. A. ; Dabiza, M.A. ; Sharaf, O.M. and Effat, B.A. 2008. A mixed culture of Propionbacterium thoenia P.127 Lactobacillus rammasus and lactobacillus palntrum as protective culture in kareish cheese Pol. J Food Nutrition sci., 5(8)4:433-441.

10. Garcia-Graells, C.; Valcks, C. and Michels, C.W. 2000. Inactivation of Eschericia coli and Listeria innocua in milk by combined treatment with high hydrostatic pressure and the lactoperoxidase system. Applied Enviro. Microbiol. and Agric. Organization of the United Nations (FAO), Rome. 66, 4173-4179.

11. Haddadin, M.S.; Ibrahim, A. and Robbinson, R.K. 1996. Preservation of raw milkby activation of the natural lactoperoxidase systems. Food Control 7, 149152. 
12. Härnulv, B.G. and Kandasamy, C. 1982. Increasing the keeping quality of milk by activation of its lactoperoxidase system. Results from Sri Lanka. Milchwissenschaft., 37: 454-7.

13. Hassan A.N.; Corredig M.; Frank, J. F. and Elsoda M. 2004. Microstructure and rheology of an (Karish) made with an exopolysaccharide - producing acidcoagulated cheese Streptococcus thermophilus strain and its exopolysaccharide non-producing genetic variant. J. Dairy Res. 71, 116-120.

14. International Dairy Federation. 1990. International standard 94B. Enumeration of Yeasts and Moulds: Colony Count Techniques at $25-C$, IDF, Brussels

15. Lin, G.C. and Chow, C.F. 2000. Studies on the lactoperoxidase system and its use in the extending the storage period of cows raw milk. J. Chinese Soc. of Animal Sci., 29 , 89-99.

16. Mehanna, N. M.; Elhami, M. and Moussa, A.M. 1998. Manufacture of Zabady from LP-ativated milk, A paper presented at the Third Saudi Symposium on Food and Nutrition, Al- Riadh, Kingdom of Saudia Arabia, 26-29.

17. Miur, D.D. and Banks, J.M.. 2000. The stability and shelf life of food. Milk and milk products. .197-219.

18. Reiter, B. And Hrnulv,H.G. 1984. The preservation of refrigerated and uncooled milk by its natural lactoperoxidase syastem. Dairy Ind. Int. 47:133.

19. SPSS 1998. Statistical Package for Social Science. SPSS Inc. Chicago, Illions, USA.

20. Stefano, G. de.; Piacquadio, P.; Sciancalepore, V. and De-Stefano, G. 1995. Effect of activation of the lactoperoxidase system on acid production in milk during storage at refrigeration temperatures., Latte., 20: 1128-1131. 


\title{
تنشيط نظام الاكتوبيروكسيديز في اللبن البقري

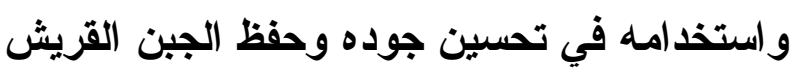

\author{
رشاد إبراهيم الأحول- صلا على النبي إبراهيم أبو الخير - حامد السيد حاتم \\ قسم بحوث كيمباء الالبان - معهُ بحوث الإنتاج الحيواني- مركز البحوث الزراعية
}

الهدف من هذه الدراسة هو تتشيط نظام الاكتوبيروكسيديز في اللبن البقرى الطازج وتأثثير

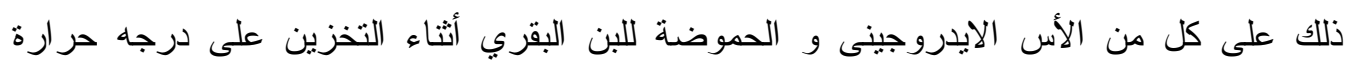

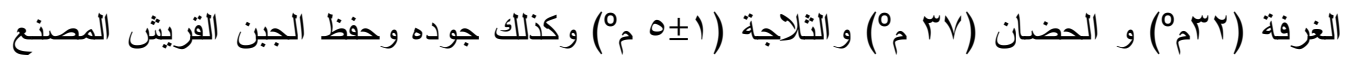
وذلك عن طريق أضافه ثيوسيانات البوتاسيوم و فوق أكسيد الأيدروجين او بير كربونات الصوديوم

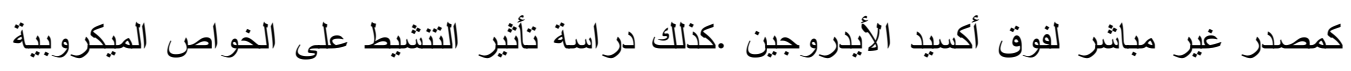
للبن وكذلك الجبن القريش الناتج.

أظهرت النتائج أن كل المعاملات التي أجريت أدت إلى تحسين جوده وقوه حفظ اللبن البقرى على درجات الحرارة المختلفة مقارنه بالعينات الغير معامله.

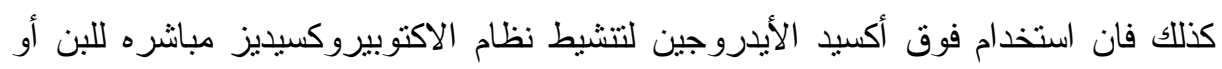
بطريق غير مباشره باضا فه بيركربونات الصوديوم لم يكن لها تأثير معنوي. في حين كانت النتائج

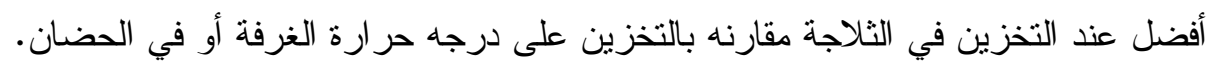
يتضح من النتائج أن تتشيط نظام الاكتوبيروكسيديز يحسن من جوده وقوه حفظ اللبن البقرى وكذلك إنتاج جبن قريش ذو مو اصفات جيده وقوه حفظ عاليه. 